\title{
Child and Adolescent Socialization in the "Music-Making for All” Festival and Competition Project
}

\section{Socialización de niños y adolescentes en el proyecto de concurso y festival "Hacer música para todos"}

Igor Krasil'nikov*

Federal State Budgetary Scientific Institution "Institute of Art Education and Cultural Studies of the Russian Academy of Education", Moscow, Russia.

ORCID: https://orcid.org/0000-0002-7623-5178

*Correspondence

Email: krasilnikov.i.m@mail.ru
Cite as:

Krasil'nikov. I., (2020). Child and Adolescent Socialization in the "Music-Making for All" Festival and Competition Project. Propósitos y Representaciones, 8 (SPE2), e687. Doi: http://dx.doi.org/10.20511/pyr2020.v8nSPE2.687 


\section{Summary}

The article examines the socialization of children and adolescents in the process of participating in the innovative festival and competition project "Music-Making for All" involving concerts in which school students perform along with professional orchestras. The basis for achieving the desired result is provided by the author's pedagogical technology of interactive music activity, which presents living through the music in the process of its creation or perception based on complementary interaction with an external sound source. A teacher survey is employed as a method of identifying the indicators of the formation of socialization and the factors affecting the socialization process. The survey reveals numerous factors determining the successful socialization of a modern person. Creating a festive mood at the concerts of the project stimulates students' interest in creative activity. High-quality repertoire orients young artists towards spiritual values. Overcoming the difficulties of music activity contributes to their personal selfaffirmation. Interaction with the instrumental ensemble becomes an effective means of creative expression of students. The communicative skills of the younger generation develop in the process of creative communication between students, professional musicians, and the public. The desire of children and adolescents to establish friendships and work in a team contributes to the formation of moral qualities. Children realize the value of labor, acquire personal qualities valuable for successful socialization, such as higher self-esteem and ethical and aesthetic personal growth, and overcome personal issues.

Keywords: Children; Adolescents; Interactive Music-Making; Professional Orchestra; Concert, Socialization.

\section{Resumen}

El artículo examina la socialización de niños y adolescentes en el proceso de participación en el innovador proyecto de festival y concurso "Hacer música para todos", que incluye conciertos en los que los alumnos de la escuela actúan junto con orquestas profesionales. La base para lograr el resultado deseado la proporciona la tecnología pedagógica del autor de la actividad musical interactiva, que presenta el vivir a través de la música en el proceso de su creación o percepción a partir de la interacción complementaria con una fuente sonora externa. Se emplea una encuesta docente como método para identificar los indicadores de la formación de la socialización y los factores que afectan el proceso de socialización. La encuesta revela numerosos factores que determinan la socialización exitosa de una persona moderna. Crear un ambiente festivo en los conciertos del proyecto estimula el interés de los estudiantes por la actividad creativa. El repertorio de alta calidad orienta a los artistas jóvenes hacia los valores espirituales. Superar las dificultades de la actividad musical contribuye a su autoafirmación personal. La interacción con el conjunto instrumental se convierte en un medio eficaz de expresión creativa de los estudiantes. Las habilidades comunicativas de la generación más joven se desarrollan en el proceso de comunicación creativa entre estudiantes, músicos profesionales y el público. El deseo de los niños y adolescentes de entablar amistades y trabajar en equipo contribuye a la formación de cualidades morales. Los niños se dan cuenta del valor del trabajo, adquieren cualidades personales valiosas para una socialización exitosa, como una mayor autoestima y crecimiento personal ético y estético, y superan los problemas personales.

Palabras clave: Niños; Adolescentes; Creación de música interactiva; Orquesta profesional; Concierto, Socialización.

\section{Introduction}

Socialization as a process of an individual entering a social environment via acquiring its norms, rules, values, knowledge, and skills is multifaceted. To function successfully in the modern society, a young person has to master various cultural elements, including the active forms of 
artistic activity, like playing music, that allow coming much closer to solving this complex problem.

Socialization of children and adolescents is one of the key objectives of the innovative festival and competition project "Music-Making for All" implemented in Russia. This project involves organizing concerts at the stages of which young artists are widely represented (from 150 to 300 in each concert) as part of various ensembles along with professional orchestras of folk instruments.

As a part of the project, 17 full-scale concerts of this kind took place in Moscow, Perm, Tambov, and Yakutsk in the period from 2015 to 2020, were all sold out, and were largely successful. More than 3,000 school and kindergarten students took part in them. The list of orchestras that performed with them includes the Nekrasov's Academic Russian Folk Instruments Orchestra of the All-Russian TV and Radio Broadcasting Company, the Osipov State Academic Russian Folk Orchestra, the folk instruments orchestra of the S. A. Zverev's National Dance Theatre of the Republic of Sakha (Yakutia), Russian folk instruments orchestras of the Tambov State Music and Pedagogical Institute named after S. V. Rachmaninov, Perm State Institute of Culture, and Perm Music College. (As an example, we provide a video recording of one of the concerts available at the following link: https://youtu.be/96Nzco5Z_Uw). In 2020, within the framework of the project "Festival and competitive movement as a form of socialization of students", the results of this scientific and applied research were summarized.

How does the socialization of children and adolescents take place in the framework of the present project, and how successful the process is?

As mentioned above, socialization presents a multifaceted process. The field of interest of modern researchers concerns its most diverse aspects relating to both children and adults, for example, the aspects related to the emotional development of children (Alwaely et. al., 2020; Yaremych \& Volling, 2020), transferring the value of labor to them (Johnson et. al., 2020), financial skills (LeBaron et. al., 2020), the formation of various types of identities including gender identity (Kate C. McLean et. al., 2019), cultural identity (Williams et. al., 2020), religious identity (Wilkins-Laflamme \& Thiessen, 2020), ethnic and racial identity (Umana-Taylor \& Hill, 2020), and the various types of education and professional activity (Richards \& Wilson, 2020; Duncheon, 2020; Fischer \& Schott, 2020).

Modern researchers also consider the festival and competition movement from various angles. The problems of preserving ethnocultural identity concern authors of articles on folk festivals (Mokgachane et. al., 2019; Vural, 2019). The problems of interaction with the sociocultural realities of our time are of interest to authors of publications on music festivals of academic genres (Berehova \& Volkov, 2019; Wallace, 2019). The problems of interaction with viewers, including the Internet setting, are the interest of researchers of music festivals of mass genres (Kitts, 2019; Kruger \& Saayman, 2019; Danielsen \& Kjus, 2019).

Thus, it can be said that the problems of socialization and the festival and competition movement are the subject of interest to modern researchers. In most cases, however, these topics are examined separately.

As previously mentioned, a new phenomenon has appeared in the framework of the festival and competition movement - the "Music-Making for All" project. The problem of socialization of children and adolescents in the process of participation in this project has not been previously considered. The relevance of the problem is determined by the need for scientific reflection of the accumulated practical experience that can serve as a basis for its pedagogical 
optimization in the conditions of the development of the project and the expanding range of young participants involved in it.

\section{Methods}

The research methods were aimed both at the study of the process of development of the interest of children and adolescents in playing music, i.e. the crucial condition ensuring their socialization in the framework of the "Music-Making for All" project, and the identification of the signs of their socialization in the process of implementing the project.

To achieve the desired pedagogical result, we employed an original pedagogical technology of interactive music activity understood as living through the music in the process of its creation or perception based on complementary interaction with an external source of sound. The implementation of this technology resulted in the simplification of music activity with the attractiveness of its product being preserved. The first aspect ensures the accessibility of the activity, and the second one contributes to its desirability. This result, therefore, contributes to improving the interest in playing music among a wide range of children and adolescents, which presents one of the priority tasks of mass music education. Solving this problem ensures, among other things, such an important educational outcome as student socialization.

A teacher survey was deployed as a method aimed at the identification of the signs of child and adolescent socialization in the context of the project. The survey question was formulated as wide as possible - it concerned the opinion of teachers on the project and the participation of their students in it. The free choice of the perspective of answers allowed us to identify whether, in the opinion of the teachers, socialization was one of the results of the project and what factors were contributing to achieving this result.

The answers provided to the question posed by the interviewers were published in several articles on the joint concerts of child ensembles and professional orchestras held as a part of the "Music-Making for All" project. An analysis of the numerous feedback messages contained in these articles, as well as the opinions of the authors being teachers themselves, regarding the participation in the project revealed the pattern of the socialization of young participants.

\section{Results}

Referring to the pedagogical technology of interactive music activity allowed teachers in multiple music and general education schools in Moscow, Perm, Tambov, and Yakutsk to organize music clubs in children's instrumental ensembles. The students participating in them perform not only at school and city concerts but also at the concerts of the "Music-Making for All" project along with the professional orchestras which indicates the effectiveness of the proposed pedagogical technology.

What was the teachers' feedback on participating in the project? Since the survey question was posed in its most general form, the answers concerned various aspects of the attitude towards the project that relate to the socialization of children and adolescents in some way.

First of all, the teachers noted the festive atmosphere characteristic of these concerts that charged the audience with strong positive emotions and self-confidence. "We are so lucky to feel like participants of such a large-scale project! Children and parents are happy, it is both a celebration and self-affirmation for them!" - S. Iu. Radchenko (Children's Music School named after W. Mozart, Moscow) (Voronova, 2017). "It was a firework of a celebration! We enjoyed it greatly" - O. A. Gureva (Children's Music School №4, Moscow) (Voronova, 2017). "Project organizers, the orchestra! Your titanic efforts resulted in a grand celebration for everyone!" $-M$. A. Ivanova (Children's Music School named after N. P. Rakov, Moscow) (Voronova, 2017). "The presence of various genres of joint music-making for children and professionals in the program 
provided the concert with festivity, brightness, amazing integrity, and harmony!" - Participants of the concert held in Perm in 2019 (Voronova, 2019). "The artistic level of the concert caused a feeling of great delight to arise, and the joint music-making united us in a single emotional impulse" - N. I. Zhunusova (International School of Almaty) (Voronova, 2016). "The feelings and impressions are indescribable! Such young, talented kids! What pride and pleasure they experienced performing musical pieces along with the folk orchestra of Yakutia" - A. Shubina (Sakha Polytechnic Lyceum, Yakutsk) (Tomskaia, 2016). "We draw inspiration from the creative unity of children's ensembles and a professional orchestra" - V. M. Koreniuk, Iu. R. Nechkina (teachers of Perm) (Voronova, 2020).

Teachers noted the benefits of creative communication with professionals that stimulate students' interest in music lessons. "Our team is 5 years old. At the beginning of education, it was attended by 12 children, and now it has about 30 children of different ages (grades from 2 to 7). To a great extent, we owe this to the 'Music-Making for All' project! Indeed, the opportunity to not only perform in a different city but also to collaborate with professional groups and perform on famous stages in Perm and Moscow is the essential argument for both the children and their parents!" (Chistina, 2018). "The involvement of children in the atmosphere of creativity allows us to hope that even if the children participating in the concert will not become professional musicians, remembering their performance with real orchestra musicians will forever keep them loyal music lovers" (Piriazeva, 2015).

Professionals charge project participants with the desire to serve art, in particular, to perform on the same stage with them in their hometowns. "Performing at joint concerts with professional teams and international school students in Moscow inspires us to organize similar concerts in Yakutsk. We strive to transfer the atmosphere of serving high art to it" $-L$. N. Gorokhova (School №33 named after Kolosova, Yakutsk) (Voronova, 2016). "We take part in all orchestra projects and hope for their support and development". - N. L. Vaganova (International School Lyceum №10, Perm) (Voronova, 2016).

According to the teachers' opinion, the important quality of responsibility for the common cause is also formed in the process of such performances. "Playing on the same stage with professional musicians, participating in the performance of wonderful works, understanding one's responsibility for a common cause is worth a lot!" (Elesina, 2016). "Being on the same stage with outstanding professionals and students from other schools is both exciting and responsible" $-T$. A. Danilova (School №83, Perm) (Voronova, 2017). "The children feel great responsibility for preparing for events, concerts, projects, and competitions!" (Chistina, 2018).

The teachers also valued the importance of attention and support of young musicians coming from the professionals. "We are grateful to the wonderful conductor, E. A. Volchkov, and the Osipov State Academic Russian Folk Orchestra for the care, attention, and support of young musicians". - T. V. Chistina (head of the "Visherianka" Children's Instrumental Ensemble, Krasnovishersk, Perm Krai) (Balashova, 2018). "The 'Music-Making for All' project attracted us with the possibility to create a joint ensemble with professional musicians and the lovers of classical music. The success of the concert exceeded all of our expectations" - O. A. Gushchina (Balakirev Children's Art School, Moscow) (Voronova, 2016).

The teachers viewed communication with professionals as a certain form of a master class and noted the effectiveness of creative communication between children and professionals for the musical development of children. "Having prepared the children for participation in the concert of this level for the first time, we understood how significant the communication between school students and professional musicians is and what a great impetus such collaboration provides for their musical development" - Teachers of Perm general education schools (Voronova, 2018a). "For these young performers using electronic and elementary instruments (and there was a total 
of about 200 of those!) performing alongside professional musicians is not only an incredible master class but also a great pleasure, an unforgettable experience" (Tomskaia, 2016).

The incredible effectiveness of this master class was viewed as a "vaccine" - the intensive improvement of the skill of amateur musicians in the process of creative communication with professionals. "Performing music on the same stage with the Nekrasov's Orchestra, the choir of Ippolitov-Ivanov Institute students, and the boys' choir of the Balakirev's Children's Art School was a sort of "vaccine" for my vocal and orchestra team... The warm creative atmosphere of the concert, meeting various choir and orchestra teams from other cities, and the joint rehearsals with the teams of various levels of preparation provide an unprecedented creative lift to the students and ensemble leaders and reveal their creative potential" - I. L. Karimova (School №83, Perm) (Voronova, 2017).

The creative growth of students in the process of communication with the masters was apparent to the teachers. "Thanks to the participation in the concert alongside the professional musicians, young musicians got the opportunity to feel like real musicians and performers. After the concert, we discussed the successes and failures in the classroom and the children shared their impressions. This wonderful experience of immersing children in music must be continued, since students have an incentive to play better”. - Tatiana Miloslavskaia (School №27, Yakutsk) (Tomskaia, 2016). "Thanks to performances with the orchestra, children who play music but are from ordinary educational institutions, from distant towns where there is no possibility to go to the theater and listen to live classical music can not only demonstrate their skills but also feel the significance of these classes for their development, increase their professionalism" $-T . V$. Chistina (head of the "Visherianka" Children's Instrumental Ensemble, Krasnovishersk, Perm Krai) (Voronova, 2017). "Having traveled to Perm and Moscow with us for several years, the parents also note the importance of these concerts, the development of the team, and, of course, admit the musical improvement of their children!" (Chistina, 2018).

Another significant theme appearing in the feedback from concert participants is the effect of the high-quality repertoire of the "Music-Making for All" concerts on the aesthetic upbringing of children and adolescents. Referring to such a repertoire met great support among the teachers. "At the concert, we performed 'The Turkish March' by L. Beethoven. The concert inspired me to let the children play the music of the great classics" - O. P. Neustroeva ("Kustuk" Kindergarten №26, Yakutsk) (Tomskaia, 2017). "At the concert, the kids from the kindergarten performed L. Beethoven's 'Turkish March' and A. Liadov's 'Musical Snuff Box/ with great pleasure. This first contact with classical music will have a beneficial effect on their spiritual and intellectual development. A delight from the live sounds of the orchestra will inspire and support their interest in classical and folk music" - E. N. Kanashina, G. A Nikulina, A. R. Khachatrian (Kindergarten of School №1788, Moscow) (Voronova, 2018b). "Words of great gratitude for the opportunity for our children to touch upon the masterpieces of world musical culture!" - T. A. Golubkina (Children's Music school named after B. A. Tchaikovsky, Moscow) (Voronova, 2017). "The most beautiful music sounded from the stage, leaving no one indifferent!... Together we were seized by a single emotional outburst of joy, kindness, and love of high art!" - E. $V$. Milonova (Children's Music School named after A. D. Artobolevskaia, Moscow) (Voronova, 2017).

An instrumental ensemble for children that plays music along with the orchestra at the concerts of the project was seen by the teachers as promising in the classroom. "A live performance of the 'Five Lubok Pictures' by a vocal ensemble sounded so cool! This will definitely be in demand! Especially since with the transition to 'by head' financing group ensembles become more rentable" - Tatiana Kuzmicheva ("Motsart" Children's Creative Center, Moscow) (Voronova, 2015). "The most interesting thing for kids is playing on highpitched bells. As they say, they look forward to being honored and trusted in this performance. They even identify the notes themselves! As one participant said: 'My soul sounds with the G note"” (Chistina, 2018). "A children's instrumental ensemble is a unique phenomenon not only 
because it enables all its participants to feel like a significant component in a multidimensional sound space, but also because it has a deep upbringing aspect. Children who can go unnoticed as solo players can reveal themselves in collective music-making. This form of learning brings a lot of positive emotions since the collective joy of the team is experienced much more intensely than the joy of a single person" (Elesina, 2019).

The vital effectiveness component of the "Music for All" project is the skills of communication between children and adolescents and the professional orchestra musicians, the audience, and young colleagues formed during the rehearsal work and the concerts. The teachers indicated the contact with professionals as life-giving for young musicians. "I would like to note the friendly atmosphere, the support from the musicians and the conductor. The children were treated like professional musicians rather than school students" - T. V. Chistina (head of the "Visherianka" Children's Instrumental Ensemble, Krasnovishersk, Perm Krai) (Voronova, 2017).

They also note the inspiring importance of support from the audience. "You get delight, a charge of cheerfulness, and energy from the 'Music-Making for All' concerts. Our children impressed the entire audience" - O. N. Bulatova (Perm) (Balashova, 2018).

The emerging desire of children to work in a team and establish friendships was viewed by the teachers as crucial. "In the ensemble performance children feel like a part of the team, gain flexibility and sociability" - L. S. Kychkina, T. D. Gabysheva ("Kencheeri" Kindergarten №2 1, Yakutsk) (Tomskaia, 2016). "Joint music-making unites the students of international schools, helps them establish friendships" - E. S. Ilinykh (A. S. Pushkin's International School, Perm) (Voronova, 2016). "Collective Music-Making develops communication skills, the ability to work in a team and do several things simultaneously - think, feel, listen, watch, and play music" (Elesina, 2019).

The teachers also noted the emerging awareness of the value of labor as a positive result of the participation of their students in the concerts of the "Music-Making for All" concerts. "Out of the proposed songs, I chose a song... that was only one minute long. But learning and rehearsing it with a big orchestra took so much time! However, after the concert, the children shared their impressions of the performance with 'adult ladies and gentlemen' playing behind their backs with great enthusiasm" - A. A. Gavrileva (Kindergarten №91, Yakutsk) (Tomskaia, 2017). "The children have conducted more than one rehearsal and understand that it is a lot of work - to create beauty, one has to invest both their skills and soul!" - O. P. Neustroeva (“Kustuk” Kindergarten №26, Yakutsk) (Tomskaia, 2017).

Another valuable psychological formation acquired by the young project participants, according to the teachers, was increased self-esteem: "Children who did not even have a special music education felt like real artists. And how did the children's eyes shine during the performance with professional musicians!" - N. V. Kulakova (classroom teacher of 3 " $B$ " class of School №83, Perm) (Voronova, 2018a). "The concerts of the 'Music-Making for All' project are a new phenomenon in music pedagogics that promotes the creative development of children, the realization of their abilities, and increased personal self-esteem" (Voronova, 2018b).

The teachers also mentioned other qualities necessary for living in society - such as moral feelings ("Thank you for your art that makes children kind and the world cleaner and brighter!" - Rafail Sadekov (Voronova, 2015)), concentration ("The artist's position on the stage accustoms them to maximum concentration, and a person with such an experience will never get confused during an exam, an interview, or a crucial performance" (Elesina, 2019)), cultural education ("Playing music broadens the child's horizons and introduces them to the diverse world of art culture" (Elesina, 2019); "Music-making for all, and not only for those who have a synthesizer, a 
flute, or a guitar at home... is not a surrogate, not a primitive entertainment, but a parallel to the traditionally established forms of learning, in other words, 'a universal music literacy campaign"” (Elesina, 2016)), and, finally, the spiritual enrichment of children ("The effectiveness of such music playing will reveal itself in the formation of the spiritual world of children" $-A$. $R$. Khachatrian, E. N. Kanashina (Kindergarten of School №1 788, Moscow) (Voronova, 2020)).

The teachers, therefore, noted that a child participating in the "Music-Making for All" project acquires a valuable multifaceted experience that can significantly enrich their future life. "Playing music along with the professionals arouses genuine interest in students. The feeling the joy from successful rehearsals and performances makes children feel comfortable in the creative team, they learn to communicate, interact, and understand each other in it. Collective musicmaking helps children to overcome their issues, promotes ethical growth, improves their selfesteem. Making music with the Nekrasov Orchestra evokes bright positive emotions from the joint activity with the wonderful masters. The collective music-making of children is an experience of an experience that will come in handy in their later life" - I. L. Karimova (School №83, Perm) (Voronova, 2018b).

\section{Discussion}

Preparation for the concerts of the "Music-Making for All" project caused children's instrumental ensemble clubs with classes based on the technology of interactive music activity to appear in many schools and kindergartens in a wide range of Russian cities. This technology makes the operational aspect of playing music easier and simultaneously stimulates the interest for it contributing to the increase in the number of children and adolescents involved in collective music-making of various types, including the one on the joint concerts with a professional orchestra. This creates the conditions for the realization of the educational potential of the "MusicMaking for All" festival and competition project, including such a significant aspect of this potential as the socialization of its young participants.

The list of the teachers' comments on their attitude to the "Music-Making for All" project presented above gives an idea of the various factors that have a positive impact on the process of socialization of students.

All concert participants primarily noted its festive atmosphere associated with the joy of living through the works of art, successfully overcoming the difficulties learning and performing it, and the emerging self-confidence. All of this stimulates the process of child and adolescent socialization.

Works of art present a whole world of meanings, images, and feelings the mastery of which is necessary for the development of the aesthetic and moral culture and creative abilities of a young person. The participants also noted the repertoire of the "Music-Making for All" project concerts being oriented towards the high art and including the best examples of folk, classic, and contemporary music. Performing this type of music becomes a factor leading children towards higher spiritual values, which can be considered an important vector of socialization.

Overcoming the difficulties associated with the preparation for the concerts with an orchestra and successful performance in it contributes to personal self-affirmation of young people. The bright emotions appearing due to this overcoming reinforce their self-confidence in performing complex socially significant activities.

The unique possibility of creative communication with professional musicians plays an invaluable role in the socialization of children and adolescents in the process of project implementation. Teachers indicate this possibility as a significant factor stimulating student interest in music lessons. 
Interaction with professionals is highly effective in terms of the musical development of students. The teachers characterized this interaction as a "vaccine" - the intensive improvement of the skill of amateur musicians in the process of creative communication with professionals. Apparent creative growth contributes to the formation of a positive self-image - a personal quality of great importance for successful socialization.

The teachers observed great benefit for students in organizing an instrumental ensemble during classes since such a composition allows for all its participants to express themselves in a multifaceted musical and sound space. Striving for self-expression becomes a key motive for the most diverse types of creative activity demanded so much in contemporary society.

The formation of communication skills, namely, the ability to communicate with musicians, the audience, and each other can be noted as a particularly significant factor in the socialization of children and adolescents. They vividly and gratefully respond to the support of professionals. The feeling of delight, a charge of cheerfulness, and energy arouses approval of school students from the audience. Participation in concert performances unites the young artists, and their desire to establish friendships and work in a team providing support for each other is essential for the formation of moral qualities as a factor of successful socialization.

Other personal qualities acquired by the project participants are also vital for socialization. Teachers noted their students realizing the value of labor, overcoming their personal issues, achieving ethical and aesthetic development, and their self-esteem increasing. Thus, according to the teachers, children and adolescents participating in the "Music-Making for All" project acquire a multifaceted experience that can significantly enrich their future life in society.

\section{Conclusion}

The original technology of interactive music activity that involves living through the music in the process of its creation or perception based on complementary interaction with an external source of sound contributes to involving a wide range of children and adolescents in playing music, among other settings, at the concerts of the "Music-Making for All" project along with professional orchestras. Teachers indicated observing various signs of successful socialization appearing in their students during these concerts due to the combined effect of several factors:

- creating a festive mood at the concerts as a significant incentive for creativity;

- reliance on the repertoire including the best examples of folk, classical, and contemporary music orienting young artists to the spiritual values;

- overcoming the difficulties associated with the preparation for a concert and participating in it that contributes to personal self-affirmation of children and adolescents;

- creative interaction with professional musicians as a stimulus for the development of students' interest in music lessons and improving their musical skills;

- interaction with an instrumental ensemble as an effective means of creative selfexpression of students;

- development of communication skills of children and adolescents in communication with professional musicians, the public, and each other;

- desire to establish friendships and work in a team as a factor in the formation of moral qualities;

- children and adolescents becoming aware of the value of labor;

- increased self-esteem;

- overcoming personal issues;

- ethical and aesthetic development. 


\section{Acknowledgments}

The results of the study were acquired as a part of fulfilling the state task of the Ministry of Education of the Russian Federation No. GZ-073-00026-20-01 "Festival and competition movement as a form of socialization of students" for 2020. The author expresses gratitude to the administration of the Federal State Budget Scientific Institution "Institute of Art Education and Cultural Studies of the Russian Academy of Education" for the scientific and financial support of the study and to professional musicians, teachers, and students and their parents from various regions of Russia for participating in the "Music-Making for All" project.

\section{References}

Alwaely, S.A. Yousif, N.B.A., Mikhaylov, A. (2020). Emotional Development in Preschoolers and Socialization. Early Child Development and Care. https://doi.org/10.1080/03004430.2020.1717480

Balashova, N. (2018). Prazdnik sostoialsia! [The celebration took place!]. Muzyka I Elektronika, $2,14-15$.

Berehova, O., Volkov, S. (2019). Piano Competitions in the Socio-Cultural Realities of Globalization. Tarih Kultur Ve Sanat Arastirmalari Dergisi - Journal of History Culture and Art Research, 8(4), 329-346.

Chistina, T. (2018). Dyshim muzykoi [Breathing music]. Muzyka I Elektronika, 4, 9.

Danielsen, A., Kjus, Y. (2019). The Mediated Festival: Live Music as Trigger of Streaming and Social Media Engagement. Convergence-The International Journal of Research into New Media Technologies, 25(4), 714-734.

Duncheon, J.C., (2020). "We Are Exposed to That College Environment": Exploring the Socialization of Early College High School Students. Community College Review, 48(2), 173-194.

Elesina, I. (2016). Stremlenie tvorit dobro [The desire to do good]. Muzyka I Elektronika, 3, 12.

Elesina, I. (2019). Razmyshleniia o proekte "Muzitsirovanie dlia vsekh" [Reflections on the "Music-Making for All" project]. Muzyka I Elektronika, 1, 12-13.

Fischer, C., Schott, C. (2020). Why People Enter and Stay in Public Service Careers: The Role of Parental Socialization and An Interest in Politics. International Review of Administrative Sciences. https://doi.org/10.1177/0020852319886913

Johnson, M.K., Mortimer, J.T., Heckhausen, J. (2020). Work Value Transmission From Parents to Children: Early socialization and Delayed Activation. Work and Occupations, 47(1), $83-119$

Kitts, T.M. (2019). The Festival for Peace: Some Ruminations on My Journey through Music. Popular Music and Society, 43(2), 163-175.

Kruger, M., Saayman, M. (2019). 'All That Jazz': The Relationship Between Music Festival Visitors' Motives and Behavioural Intentions. Current Issues in Tourism, 22(19), 23992414.

LeBaron, A.B., Marks, L.D., Rosa, C.M., Hi, E.J. (2020). Can We Talk About Money? Financial Socialization Through Parent-Child Financial Discussion. Emerging Adulthood. https://doi.org/10.1177/2167696820902673

McLean, K.C., Boggs, S., Haraldsson, K. (2019). Personal Identity Development in Cultural Context: The Socialization of Master Narratives About the Gendered Life Course. International Journal of Behavioral Development. https://doi.org/10.1177/0165025419854150.

Mokgachane, T., Basupi, B., Lenao, M. (2019). Implications of cultural commodification on the authenticity of iKalanga music: a case of Domboshaba traditional music festival in Botswana. Journal of Tourism and Cultural Change, pp 1-13.

Piriazeva, E. (2015). "Muzitsirovanie dlia vsekh" - novaia forma sovremennogo muzykalnogo iskusstva ["Music-Making for All" - a new form of modern musical art]. Muzyka I Elektronika, 2, 18. 
Richards, K.A.R., Wilson, W.J. (2020). Recruitment and initial socialization into adapted physical education teacher education. European Physical Education Review, 26(1), 54-69.

Tomskaia, A. (2016). V garmonii s muzykoi - k vershinam uspekha [In harmony with music - to the heights of success]. Muzyka I Elektronika, 3, 12.

Tomskaia, A. (2017). Pervye shagi v muzyku [First steps in music]. Muzyka I Elektronika, 2, 5.

Umana-Taylor, A.J., Hill, N.E. (2020). Ethnic-Racial Socialization in the Family: A Decade's Advance on Precursors and Outcomes. Journal of Marriage And Family, 82(1), 244-271.

Voronova, E. (2015). Muzitsiruem vmeste! [Playing music together!]. Muzyka I Elektronika, 4, 9-10.

Voronova, E. (2016). Na stsene - professionaly i shkolniki [Professionals and school students on stage]. Muzyka I Elektronika, 3, 11.

Voronova, E. (2018a). Osennee muzitsirovanie [Autumn music-playing]. Muzyka I Elektronika, 4, 7-8.

Voronova, E. (2018b). Proekt "Muzitsirovanie dlia vsekh" na Permskoi zemle ["Music for all" project in Perm]. Muzyka I Elektronika, 1, 7-8.

Voronova, E. (2019). Novye vozmozhnosti muzitsirovaniia [The new possibilities of playing music]. Muzyka I Elektronika, 3, 16.

Voronova, E., Gushchina, O. (2017). Vserossiiskii proekt "Muzitsirovanie dlia vsekh" [AllRusssian project "Music-Making for All"]. Muzyka I Elektronika, 2, 16-17.

Voronova, Elena (2020). Shag v budushchee (na kontserte pamiati D.B. Kabalevskogo) [A step into the future (at a concert in memory of D.B. Kabalevskii)]. Muzyka I Elektronika, 1, 8-9.

Vural, F.G. (2019). Bear Festival in Yakut Turks, Khanty-Mansi and Nenets and Musical Instruments Used in the Festival. BILIG, 88, 83-112.

Wallace, E.M. (2019) A History of the "Festival of the Arts" at Southwest Virginia Community College (1995-2018): Community Service through Music. Journal of Historical Research In Music Education. https://doi.org/10.1177/1536600619864703

Wilkins-Laflamme, S., Thiessen, J. (2020). Religious Socialization and Millennial Involvement in Organized and Digital Nonbelief Activities. Secularism \& Nonreligion, 9.

Williams, C.D., Bravo, D.Y., Umana-Taylor, A.J., Updegraff, K.A., Jahromi, L.B., MartinezFuentes, S., Elias, M.D. (2020). Intergenerational Transmission of Cultural Socialization and Effects on Young Children's Developmental Competencies Among Mexican-Origin Families. Developmental Psychology, 56(2), 199-207.

Yaremych, H.E., Volling, B.L. (2020). Sibling Relationships and Mothers' and Fathers' Emotion Socialization Practices: A Within-Family Perspective. Early Child Development And Care, 190(2), 195-209. 